Diabetologia 8, 185-188 (1972)

(C) by Springer-Verlag 1972

\title{
Studies on the Site of Action of Tolbutamide in the Lipolytic System
}

\author{
C. Rosak, K.M. Bartelt, J. Beyer and K. SchöfHLtyg \\ Center of Internal Medicine, Johann Wolfgang Goethe-University, Frankfurt/Main, Department of Endocrinology \\ (Director: Prof. Dr. K. Schöffling) Frankfurt/M., Germany \\ Received : November 8, 1971, accepted : February 24, 1972
}

Summary. The antilipolytic effect of tolbutamide was studied under different conditions in isolated rat adipose tissue, using norepinephrine, theophylline and dibutyryl $3^{\prime}, 5^{\prime}$-AMP as lipolysis-stimulating agents. A selective blockade was performed with alpha and beta-blocking agents (phentolamine and Kö 592) to investigate a possible relation of tolbutamide to the adrenoceptive structures of the fat cell. - 1. Tolbutamide exerts an antilipolytic effect on norepinephrine and theophylline-stimulated lipolysis in two different concentration ranges. -2 . When using dibutyryl $3^{\prime}, 5^{\prime}$-AMP, this biphasic pattern disappears. - 3. Tolbutamide shows an additional antilipolytic activity in adipose tissue pretreated with the beta blocker Kö 592, whereas this effect could not be obtained after pretreatment with the alpha blocker phentolamine. - From the results obtained the conclusion is drawn that tolbutamide, like phentolamine, at least in concentrations ranging from 12.5 to $50 \mu \mathrm{g} / \mathrm{ml}$, influences a reaction subsequent to the formation of cyclic $3^{\prime}, 5^{\prime}$-AMP.

Etude sur le site d'action du tolbutamide dans le système lipolytique

Résumé. L'effet antilipolytique du tolbutamide a été examiné dans différentes conditions à l'aide du tissu adipeux isolé du rat. Pour la stimulation de la lipolyse, on a employé de la noradrénaline, de la théophylline et du dibutyryl $3^{\prime}, 5^{\prime}$-AMP. Pour découvrir une relation possible entre le tolbutamide et les structures adrénoceptives de la cellule adipeuse, on a fait un blocage sélectif avec des agents bloquant les récepteurs alpha et bêta (phentolamine et $\mathrm{Kö} \mathrm{592).} \mathrm{-} \mathrm{1.} \mathrm{Le} \mathrm{tolbutamide} \mathrm{a} \mathrm{un} \mathrm{effet} \mathrm{anti-}$ lipolytique, qui agit dans deux zones différentes de concentration, sur la lipolyse stimulée par la noradrénaline et la théophylline. - 2. En utilisant le dibutyryl $3^{\prime}, 5^{\prime}$ AMP ce modèle biphasique n'existe pas. - 3. Dans le tissu prétraité avec le bêta bloquant, Kö 592, le tolbutamide a un effet antilipolytique supplémentaire; dans le tissu prétraité avec l'alpha bloquant, phentolamine, cet effet ne se produit pas. - Ces résultats mènent à la conclusion que le tolbutamide, au moins dans une zone de concentration de $12,5-50 \mu \mathrm{g} / \mathrm{ml}$, agit sur une réaction après la formation de $3^{\prime}, 5^{\prime}$-AMP cyclique.

Untersuchungen zum Angriffspunkt des Tolbutamid im lipolytischen System

Zusammenfassung. Der antilipolytische Effekt von Tolbutamid wurde unter verschiedenen Bedingungen am isolierten Rattenfettgewebe untersucht. Als Stimulatoren der Lipolyse wurden Nordrenalin, Theophyllin und Dibutyryl $3^{\prime}, 5^{\prime}$-AMP verwendet. Um eine mögliche Verbindung von Tolbutamid mit den adrenoceptiven Strukturen der Fettzelle herauszufinden, wurde eine selektive Blockade mit alpha- und beta-blockierenden Substanzen (Phentolamin und $K \ddot{~}$ 592) durchgeführt. - 1. Tolbutamid wirkt in zwei verschiedenen Konzentrationsbereichen auf die Noradrenalin- und Theophyllin-stimulierte Lipolyse antilipolytisch. - 2. Bei Verwendung von Dibutyryl $3^{\prime}, 5^{\prime}$-AMP geht dieses biphasische Muster verloren. 3. In Fettgewebe, welches nit dem beta-Blocker Kö 592 vorbehandelt wurde, wirkt Tolbutamid zusätzlich antilipolytisch; in Fettgewebe, welches mit dem alpha-Blocker Phentolamin vorbehandelt wurde, tritt dieser Effekt nicht auf. - Diese Ergebnisse führen zu dem Schluß, daß Tolbutamid wie Phentolamin zumindest im Konzentra. tionsbereich von $12,5-50 \mu \mathrm{g} / \mathrm{ml}$ auf eine Reaktion nach der Bildung von cyclischem $3^{\prime}, 5^{\prime}$-AMP wirkt.

Key words: Tolbutamide, antilipolytic activity, lipolytic system, adipose tissue, adrenoceptive structures.
Besides the well-known beta cytotropic effect of sulfonylureas some other effects not mediated by insulin have been described (Feldmann and Lebovitz, 1969). Generally, the latter are summarized as "extrapancreatic effects". Thus, sulfonylureas exert an inhibiting effect upon the lipolytic system of adipose tissue, as demonstrated by Renold et al. (1959), Stone et al. (1966), Stone and Brown (1967), Faulhaber et al. (1969) and Stork et al. (1969).

It is well established that lipolysis in rat adipose tissue is controlled by the tissue level of cyclic AMP (Butcher et al., 1968; Hynie et al., 1966), which is regulated by the adenyl cyclase system and phosphodiesterase activity. Agents stimulating either the activity of adenyl cyclase or inhibiting the activity of phosphodiesterase are known to increase the tissue level of cyclic AMP and thus activate the triglyceridesplitting lipase system.

For further elucidation of the antilipolytic action of tolbutamide we have studied its effect upon norepinephrine-, dibutyryl $3^{\prime}, 5^{\prime}$-AMP and theophyllinestimulated lipolysis. In addition, a possible interaction of tolbutamide with the alpha and beta adrenergic receptor sites in adipose tissue was investigated.

\section{Method}

Male Wistar rats of 120 to $160 \mathrm{~g}$ were fed ad libitum and sacrificed by decapitation. The epididymal fat pads were removed and washed in Krebs-Ringer-Bicarbonate-Albumin buffer (KRBA). $0.5 \mathrm{~g}$ adipose tissue was 


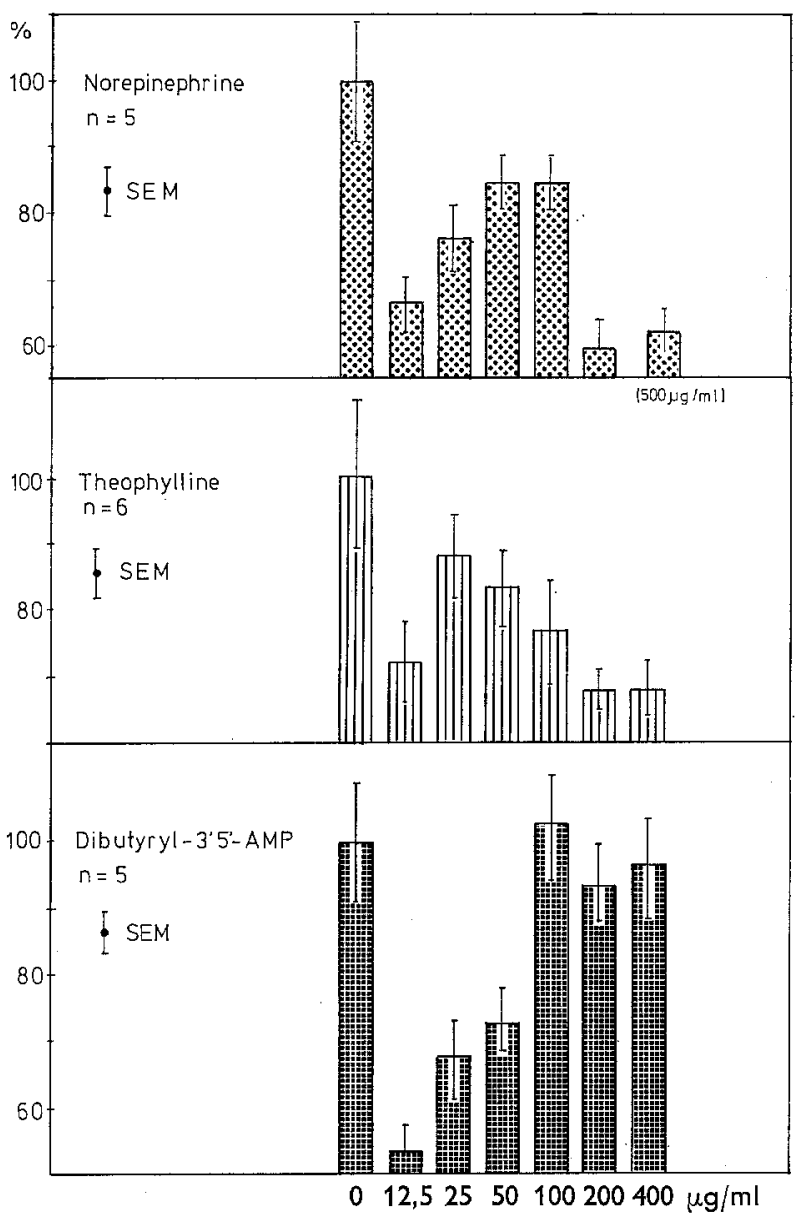

Fig. 1. Tolbutamide action upon lipolysis stimulated with different agents in rat epididymal fat pieces. Glycerol, liberated by the stimulatory agents in the absence of tolbutamide served as control and was set as $100 \%$. Depression of enhancement of lipolysis caused by tolbutamide was calculated as percent of control cut into pieces and transferred to $25 \mathrm{ml}$ polyethylene vials containing glucose-free KRBA buffer $(2 \%$ albumin; $\mathrm{pH}$ 7.4). After addition of the various lipolytic agents and tolbutamide in different concentrations, the preparation was diluted to $10 \mathrm{ml}$. The vials were gassed with carbogen $\left(95 \% \mathrm{O}_{2} ; 5 \% \mathrm{CO}_{2}\right)$, closed tightly and incubated at $37^{\circ} \mathrm{C}$ in a Warburg metabolic shaker for $60 \mathrm{~min}$. In experiments with sympathicolytica, phentolamine and Kö 592 were added $15 \mathrm{~min}$ before this incubation phase. At the end of the incubation period an aliquot of the medium was removed for determination of free glycerol (Eggstein and Kreutz, 1966), as an index of lipolytic activity (Wieland and Suyter, 1957). After correction for basal lipolysis, the glycerol release induced by the lipolysis-stimulating agents was expressed as $100 \%$ and the depression of glycerol release by tolbutamide and the sympatholytica was calculated.

Reagents, added in vitro:

1. Bovine serum albumin, "reinst", Behringwerke Marburg:

2. Norepinephrine, Arterenol ${ }^{\circledR}$, Farbwerke Hoechst, Frankfurt

3. Tolbutamide, Rastinon ${ }^{\circledR}$, Farbwerke Hoechst, Frankfurt

4. Kö 592, Boehringer, Ingelheim

5. Theophylline, Euphyllin ${ }^{\circledR}$, BYK Gulden, Konstanz

6. $\mathrm{N}^{6}-2^{\prime} 0$-Dibutyryl-adenosin- $3^{\prime}, 5^{\prime}$-monophosphat, cyclisch, Boehringer, Mannheim

7. Phentolamine, Regitin ${ }^{\circledR}$, CIBA AG, Wehr/Baden

\section{Results}

In preliminary experiments, the dose-relationship of norepinephrine and theophylline on lipolysis was established. Both agents, but in different concentra-

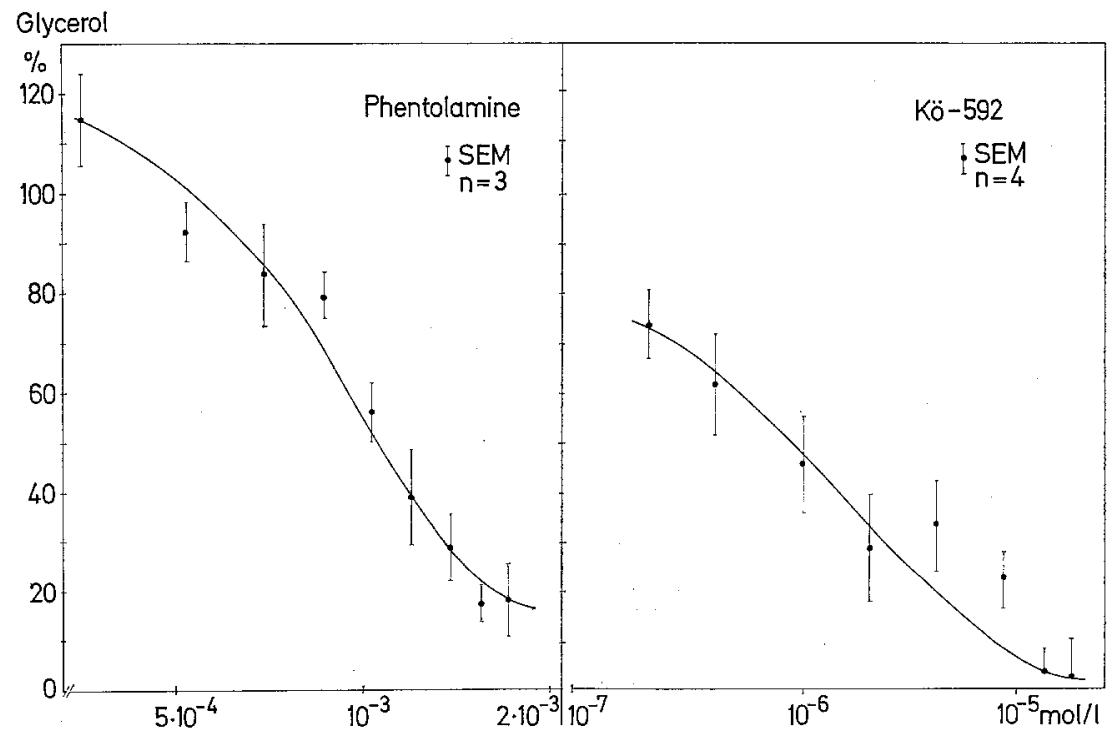

Fig. 2. Dose response curves demonstrating the inhibitory activity of the alpha-blocker phentolamine and the betablocker Kö 592 upon norepinephrine-induced lipolysis 
tions, exert nearly the same maximum lipolytic activity, a four-fold increase of basal glycerol release. In all further experiments, almost equipotent concentrations, causing a submaximal increase of lipolysis, i.e. $3 \times 10^{-7}$ $\mathrm{M}$ norepinephrine and $1.25 \times 10^{-3} \mathrm{M}$ theophylline, were used. For dibutyryl $3^{\prime}, 5^{\prime}$-AMP we did not establish a special dose response curve. Based on the results of Aulich et al., 1967, and Moskowitz and Fain, 1969 , we have chosen a concentration of $10^{-3} \mathrm{M}$, which constantly enhanced the lipolysis, increasing glycerol release to 2.5 -fold above basal values $(1.09+0.04$ to $2.40 \pm 0.17 \mathrm{mg} \%$ ).

Tolbutamide caused a significant antilipolysis in low $(12.5-25 \mu \mathrm{g} / \mathrm{ml})$ and high concentrations $(200-$ $500 \mu \mathrm{g} / \mathrm{ml}$ ). This inhibitory effect seemed to be partially lost in the concentration range $50-100 \mu \mathrm{g} / \mathrm{ml}$. The change from minor to strong inhibition of lipolysis was variable in concentrations from $50-200 \mu \mathrm{g} / \mathrm{ml}$, with the different lipolytic agents norepinephrine and theophylline. In contrast, using the synthetic nucleotide dibutyryl $3^{\prime}, 5^{\prime}$-AMP as stimulator of lipolysis, this biphasic pattern was lost, but the low concentrations of tolbutamide exerted an even stronger antilipolytic effect. The depression of glycerol release by high concentrations of tolbutamide was no longer demonstrable (Fig. 1).

Since epinephrine, norepinephrine etc. act via the adrenergic receptors in vivo and in vitro as potent stimulators of lipolysis, the alpha and beta sympathicolytic agents block lipolysis in a dose-dependent way (Fig. 2). Both substances are reported to exert their effect on different structures of the fat cell, the beta blocker Kö 592 on the adenyl cyclase (Stock and Westermann, 1966) and the alpha blocker phentolamine on the triglyceride lipase system (Hynie et al., 1969). Therefore, experiments with the combined administration of tolbutamide and the alpha or beta-blocking agents were carried out (Fig. 3). The sympathicolytic drugs were used in a concentration which, in preliminary experiments (Fig. 2), was found to cause a depression of lipolysis of about $30 \%\left(2.2 \cdot 10^{-7} \mathrm{M}\right.$ for Kö 592 and $7.5 \cdot 10^{-4}$ M for phentolamine; black bar in Fig. 3). Additional antilipolysis of tolbutamide was only observed in fat minces pretreated with Kö 592 (. - - - .), whereas the sulfonylurea failed to show any further effect in the presence of phentolamine (.—.). It can be stated also that in these experiments with Kö 592 the biphasic pattern to tolbutamide action remains visible.

\section{Discussion}

An antilipolytic effect of tolbutamide has already been described by several authors (Renold et al., 1959; Stone et al., 1966; Stone and Brown, 1967; Faulhaber et al., 1969; Stork et al., 1969), but in all these experiments, tolbutamide concentrations below $50 \mu \mathrm{g} / \mathrm{ml}$ have not been studied. In this range of concentration
$(12.5-50 \mu \mathrm{g} / \mathrm{ml})$, we were able to detect a considerable antilipolytic effect of tolbutamide, as already described elsewhere (Rosak et al., 1970). Our results confirm the antilipolytic potency of tolbutamide in vitro. On the other hand, they do not support a simple dose-response relationship, but are in favour of a more complex situation, tolbutamide exhibiting its antilipolytic activity in two separate ranges of concentration. This biphasic pattern is observed if the stimulation of lipolysis is mediated by a direct or indirect accumulation of eyclic $3^{\prime}, 5^{\prime}$-AMP. In the presence of the synthetic nucleotide itself, the antilipolytic activity of tolbutamide is demonstrable only in low concentrations, but is missing in concentrations above $50 \mu \mathrm{g} / \mathrm{ml}$.

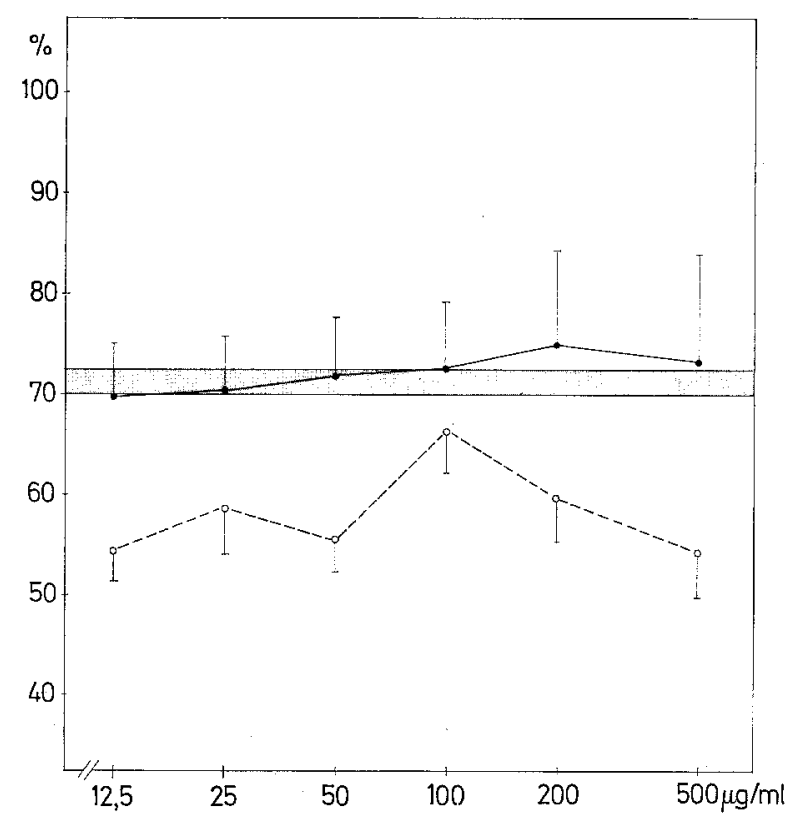

Fig. 3. Effect of tolbutamide on glycerol release of lipolysis stimulated with norepinephrine in epididymal rat adipose tissue pretreated with phentolamine —_ and Kö 592 . . . . . . . The black bar represents the inhibition of lipolysis caused by the blocking agents

This phenomenon prompts the suggestion that high concentrations of tolbutamide exhibit their antilipolytic activity by reactions which cause a depletion of the intracellular cyclic $3^{\prime}, 5^{\prime}$-AMP level. On the other hand, low sulfonylurea concentrations seem to interfere with a subsequent reaction, possibly with the activation of triglyceride lipase by the nucleotide itself.

Adipose tissue is known to behave biochemically and functionally as an organ innervated by the sympathetic (Stock and Westermann, 1966). With regard to these relations, the interference of tolbutamide with the adrenoceptive structures in adipose tissue has been investigated. The antilipolytic reaction of alpha and beta sympathicolytic agents on norepinephrine-stimulated lipolysis was taken as a model to be compared with the action of tolbutamide. In the concentration 
range from $12.5-500 \mu \mathrm{g} / \mathrm{ml}\left(4.6 \times 10^{5}\right.$ to $\left.1.85 \times 10^{3} \mathrm{M}\right)$ tolbutamide is able to induce additional antilipolysis in adipose tissue pretreated with the beta blocker, whereas it is unable to do this in a tissue pretreated with the alpha blocker. Since we know nothing about the affinity and the intrinsic activity of tolbutamide with respect to the adrenergic receptors in adipose tissue, it is difficult to explain this phenomenon. Theoretically, one would expect an additive effect of two synchronously administered and synergistic agents, if they operate on different receptors. Thus, if two agents having affinity, but no intrinsic activity, compete for the same receptor, the substance with the lower affinity to the binding sites of the receptor would not be able to reveal its blocking properties. These theoretical considerations applied to our experiments would permit the following interpretations: The results obtained with the $\mathrm{Kö}$ 592-pretreated tissue demonstrate that tolbutamide does not operate upon the beta adrenergic receptor, but provides additional antilipolysis by blocking the alpha receptor. On the other hand, the inability of tolbutamide to increase the inhibition of lipolysis in the presence of phentolamine has to be explained by its lower affinity to the alpha receptor compared with that of phentolamine.

The biochemical site of action of phentolamine was shown by Peterson et al. (1968) to interfere with the reaction subsequent to the formation of cyclic $3^{\prime}, 5^{\prime}$ AMP. Furthermore, Hynie et al. (1969) were able to inhibit directly the triglyceride lipase activity in adipose tissue homogenates with the same substance.

Therefore, if tolbutamide acts in a similar way to phentolamine, it would be expected to interfere with the reaction subsequent to the formation of cyclic $3^{\prime}, 5^{\prime}$-AMP. In fact, tolbutamide exerted its antilipolytic activity in those experiments where dibutyryl $3^{\prime}, 5^{\prime}$. AMP was used as the lipolysis-stimulating agent. Further experiments should clarify whether this effect of the sulfonylurea is due to a direct inhibition of triglyceride lipase activation by cyclic $3^{\prime}, 5^{\prime}$-AMP.

Acknowledgement. We are indebted to Boehringer, Mannheim, for their generosity to supply us with dibutyryl 3',5'-AMP, and to Boehringer, Ingelheim, for their kind donation of Kö 592 .

\section{References}

Aulich, A., Stock, K., Westermann, E.: Lipolytic effects of cyclic adenosine $3^{\prime}, 5^{\prime}$-monophosphat and its butyryl derivates in vitro, and their inhibition by $\alpha$ - and $\beta$ adrenolytics. Life Sci. 6, 929-938 (1967).

Butcher, R.W., Baird, C.E., Sutherland, E.W.: Effects of lipolytic and antilipolytic substances on adenosine $3^{\prime}, 5^{\prime}$-monophosphat levels in isolated fat cells. J. biol, Chem. 243, 1705-1712 (1968).
Eggstein, M., Krentz, F.H.: Eine neue Bestimmung der Neutralfette im Blutserum und Gewebe. Klin. Wschr. 44, $262(1966)$.

Faulhaber, J.D., Ditschuneit, H., Ditschuneit, H.H.: Die Wirkung von Sulfonylharnstoffen HB 419 (Glibenclamid), Tolbutamid und Tolazamid auf die Lipolyse isolierter menschlicher Fettzellen. Arzneimittel-Forsch. $8 a, 1476-1478(1969)$.

Feldmann, J.M., Lebovitz, H.E.: Appraisal of the extrapancreatic actions of sulfonylureas. Arch. Intern. Med. 123, 314-322 (1969).

Hynie, S., Krishna, G., Brodie, B.B.: Theophylline as a tool in studies of the role of cyclic adenosine $3^{\prime}, 5^{\prime}$-monophosphat in hormone-induced lipolysis. J. Pharmacol. exp. Ther. 153, 90-96 (1966).

- - - Differentiation of mechanisms of the antilipolytic actions produced by alpha and beta adrenergic blocking agents. Pharmacology 2, 129-137 (1969).

Moskowitz, J., Fain, J.N.: Hormonal regulation of lipolysis and phosphorylase activity in human fat cells. $J$. clin. Invest. 48, 1802-1808 (1969).

Peterson, M.J., Patterson, C., Ashmore, J.: Effects of antilipolytic agents on dibutyryl cyclic AMP induced lipolysis in adipose tissue. Life Sci. 7, 551-560 (1968).

Renold, A.E., Zahnd, G.R., Jeanrenaud, B., Boshell, B. R.: Some effects of tolbutamide and chlorpropamide in vitro. Ann. N. Y. Acad. Sci. 74, 490-498 (1959).

Rosak, C., Bartelt, K.M., Cordes, U., Haupt, E., Beyer, J., Schöffling, K.: Comparative studies on the antilipolytic activity of tolbutamide and glibornuride (Ro 6-4563) in the isolated fat pad of the rat. "International Symposium on Recent Hypoglycemic Sulfonylureas Mechanisms of Action and Clinical. Indication", Basel, October 2-3, 1970.

Stock, K., Westermann, E. : Hemmung der Lipolyse durch $\alpha$ - und $\beta$-Sympathicolytica Nicotinsäure und Prostaglandin $\mathrm{E}_{1}$. Naunyn-Schmiedebergs Arch. Pharmak. u. exp. Path. 254, 334-354 (1966).

- - Competitive and non-conpetitive inhibition of lipolysis by $\alpha$ - and $\beta$-adrenergic blocking agents, methoxymine derivates and prostaglandin $\mathbf{E}_{1}$. Life Sci. 5, $1667-1678$ (1966).

Stone, D.B., Brown, J.D., Cox, C.P.: Effect of tolbutamide and phenformin on lipolysis in adipose tissue in vitro. Amer. J. Physiol. 210, 26-30 (1966).

-_ - The in vitro effects of tolbutamide in adipose tissue. In: "Tolbutamide ... After Ten Years", ed. Butterfield, W.J.H. and van Westering, W., Excerpta Medica Foundation, Amsterdam 1967, p. 202.

Stork, H., Schmidt, F.H., Bänder, A., Pfaff, W.: Einfluß von HB 419 - einem neuen oralen Antidiabeticum auf den Fettstoffwechsel. Arzneimittel-Forsch. 8a, 1373-1378 (1969).

Wieland, O., Suyter, M.: Glyzerokinase: Isolierung und Eigenschaften des Enzyms. Biochem. Z. 329, 320-326 (1957).

Christoph Rosak, cand. med. Zentrum der Inneren Medizin der Johann Wolfgang Goethe-Universität Frankfurt am Main

Abteilung für Endokrinologie

D-6 Frankfurt am Main 70

Ludwig-Rehn-Straße 14

Germany 